\title{
Loan Words in Modern English and Their Features
}

\author{
ZHOU Li-na \\ China Youth University of Political Studies, Beijing, China
}

\begin{abstract}
English language, as a global language, is exerting greater influence on the world. It has been enlarging along with the development of the society, the progress of science and technology by the way of borrowing from other languages such as French, German, Italian, Spanish, Russian, Chinese, Japanese, and Arabic in the fields of politics, culture, education, economics, science, and technology. Borrowing or loan word has become an important part in the process of English vocabulary acquisition. This paper studies modern English loan words, summarizes types of loan words, and makes a tentative analysis of their features with the attempt to facilitate English learning in an effective way.
\end{abstract}

Keywords: modern English, loan words, features

\section{Introduction}

A loan word or borrowing is a word adopted from a source language and incorporated into a recipient language without translation. With rapid process of globalization, interconnections among countries in areas of economics, politics, culture, science, and technology get strengthened. As a result of this, English, as the world language, has borrowed a large number of words from foreign languages like French, German, Italian, Russian, Chinese Japanese, Greek, Spanish, Arabian, etc. According to surveys, the percentage of modern English words derived from each language is $29 \%$ from French, 29\% from Latin, 26\% from German, and 6\% from Greek, the rest accounting for 6\%. This paper probes into loan words in modern English with the aim to facilitate English learning in EFL (English as a Foreign Language).

\section{Modern English Loan Words}

\section{Chinese Origin}

Words with Chinese origin have entered the English language, most of which were loan words from Chinese itself. However, Chinese words have also entered indirectly via other languages, especially Korean and Japanese. The latter part of 20th century witnessed greater influx of loan words with Chinese origin into English via modern international communication, especially after the 1970s when the People's Republic of China opened its door to the outside world. They include Fengshui, wirefu, Sifu, lose face, one country two systems, tuhao, dama, buzheteng, no zuo no die, Lao-tzu, Tai-chi, Tao, taikonaut, Cultural Revolution, planned commodity economy, iron rice bowl, township enterprises, little emperor, one child policy, vegetable basket project, Lianghui, etc.

ZHOU Li-na, associate professor, master, Department of English Language and Literature, China Youth University of Political Studies. 
Since China has profound and rich food culture, Chinese dishes entered the West. Quite a few English loan words from Chinese appeared on the menu of the western restaurants: Mushu Pork, Dim Sum, Ramen, Wonton, ginkgo, ginseng, lychee, Chaomein, etc. Internet loan words of Chinese appear in numbers, too: human flesh search, play hide and seek, to get soy sauce, wechat, weibo, knock off, alibaba, etc.

\section{French Origin}

English contains many words of French origin in art, sports, money, diplomacy, etc. Most are pronounced according to the English rules of phonology. Usually if the word or phrase retains French diacritics or is usually printed in italics, it has retained its French identity. Others may seem correct to English speakers, but not recognized as such by French speakers as many of them are now defunct or have changed in meaning. Presently many of the menus in British and American restaurants are in French: extraordinary, fromage blanc, amusegueule, mesclun, nouvelle cuisine, aperitifs, pain au chocolat, café au lait, entrée, jambalaya, chowder, etc. Other borrowings are related to politics, sports, fashion, and art such as bon chic bon genre, chef d'équipe, parkour, soigneur fonctionnaire, franc fort, touché, dossier, déjà vu, vis-à-vis, faux pas, nouveau riche, rentier, jamais vu, elite, ambiance, collage, repertoire, entourage, tranche, toboggan, bête noire, enfant terrible, etc.

\section{German Origin}

English and German descend from the same ancestor language-West Germanic and because of this, some English words are essentially similar to their German lexical counterparts, either in spelling (Hand, Sand, Finger) or pronunciation ( fish $=$ Fisch, mouse $=$ Maus). Another feature is that many English words have been borrowed directly from German in recent years, for which most of them will be recognized by many English speakers. Loan words in food and drink include delicatessen, Gummi bear, Berliner, weisse, kirschwasser, hefeweizen, schnaps, spritzer, stein, pilsner, hasenpfeffer, lager, bundt cake, kipfel, biergarten, bratwurst, muesli, pretzel, pumpernickel, rollmops, sauerkraut, etc; Sports borrowings are rucksack, turnverein, kletterschuh, volkssport, blitz, wanderlust, Gemütlichkeit, Gesundheit, etc. Other loan words of daily life are zeitgeist, Gestalt, doktorvater, festschrift, kitsch, privatdozent, Professoriat, gemutlich, kaffeeklatsch, kaput, wrangle, yodel, strudel, schadenfeude, waldsterben.

\section{Italian Origin}

Words of Italian origin mostly have something to do with cuisine: bresaola, bruschetta, caffèlatte, calzone, focaccia, mascarpone, panzanella, radicchio, rucola, taleggio, confetti, lasagne, pasta, broccoli, zabaglione, linguini, spumante, zucchini. Music and architecture is another area of borrowing: Adagio, Allegro, alto, aria, bravo, cello, concerto, duet, mandolin operetta, tempo, viola, fresco, patio, grotto, graffiti, terra-cotta; Borrowings abound in fashion and furniture: baldachin, brocade, costume, jeans, Muslin, Organza, parasol, stiletto, umbrella valise; Borrowings in other fields include: casino, gondola, lido, mafial, mafioso, malaria, zany, paparazzi, snaparazzi, masquerade, cascade, bimbo, dildo, lothario, segragation, dodge, ghetto, marfia, arsenal, venture.

\section{Spanish Origin}

Many Spanish words have entered English from three primary sources: Many of them entered American English in the days of Mexican or Spanish cowboys working in what is now the US Southwest. The second primary source is by way of business transactions and trade. The third major source is the names of foods whose 
names have no English equivalent. Many of the words changed meaning upon entering English, often by adopting a narrower meaning than in the original language. Spanish loan words are fajitas, taco, ancho, tortilla, chipotle, habanero, maquiladora, palapa, sinsemilla, telenovela, tomatillo, tonto, savvy, Lolita, El Nino, silo, bonanza plaza, salsa, fiesta, avocado, burrito, bizarre, bravo, guerrilla, chili, etc.

\section{Japanese Origin}

Words of Japanese origin have entered English language. Some words are simple transliterations of Japanese words for concepts inherent to Japanese culture, but others are of Chinese origin which were first exposed to English via Japan. It is estimated that 900 Chinese characters entered English, 200 of which entered English via Japanese due to its prominence in international economy. They include words from food, popular culture, economy such as Nori, ginkgo, ramen, teppanyaki, kombu, matsutake, sashim, wakame; anime, ikabana, karaoke, manga, tamagotchi, kamikazek, araoke, sashimi, Otaku, Otaku girl; kaizen, kanban, karoshi, keiretsu, tsunami, zaitech.

\section{Russian Origin}

Compared to other source languages, very few of the loan words in English come from Russian. Direct borrowing picked up heavily in the 20th century with the establishment of the Soviet Union as a major world power. Most of them are used to refer to things and concepts specific to Russia, Russian culture, politics, and history. Common usages are cosmonaut intelligentsia, glasnost, Lunokhod, Mir, Lunik, Politburo, sputnik, icon, mammoth, muzhik, samovar, Troika, etc.

\section{Greek and Latin Origin}

Most of the loan words from Latin and Greek are special and science terms. For example, abducens nerve, candida, animation, millennium, decapitation, manicure, exvivo, realia from Latin, gyro, ultrasaurus, television, bouzouki, olive from Greek, etc. One popular word needs mentioning is Mega. It was used as a morpheme from the 80 s of 20th century meaning extra large and become productive, for example, mega house, megasuperstar, megavitamin, megawatt, megavolt, megaton, megastore, megatechnology.

\section{Arabic Origin}

English loan words have been borrowed directly from Arabic or indirectly by passing from Arabic into other languages and later into English. Examples are Nadir, artichoke, arsenal, zenith, hijab, doner kebab, imam bayildi, sheshbesh, gal, Hamas, Hezbollah, Taliban or Taleban, bedouin, emir, jakir, gazelle, giraffe, harem, hashish, lute, minaret, mosque, myrrh, salaam, sirocco, sultan, vizier, bazaar, caravan, etc.

\section{Features of English Loan Words}

\section{Variety}

English and American culture are famous for their multiculture. American culture is even dubbed as "melting pot". They assimilate and absorb different foreign languages brought by immigrants to the land. These include French, German, Italian, Spanish, Russian, Japanese, Hindu, Chinese, Arabian, African languages, to name just a few. It is reported that $80 \%$ of English words derive from loan words, concerning culture, economics, art, sports, medicine, health, science, and technology making the language colorful and vigorous. 


\section{Flexibility in Word Formation}

Loan words come into English language by the way of zero substitution, substitution, and partial substitution. The methods of formation are flexible and various making the language concise. For example, Fenshui in Chinese, Otaku in Japanese, fajitas in Spanish are borrowed directly from the donor language. Loan words Lunik and parkour are substituted with spelling and pronunciation changes. Other loan words such as taikonaut from Chinese, chauffeur in French, volksport from German, paparazzi from Italian are partially substituted in either pronunciation or spelling. Some loan words transfer meanings aquiring new meaning after entering into English such as camping (campsite) in Argentina and wok (stir fry) in Chinese.

\section{Assimilation of Slangs Phrases and Aphorisms From Other Languages}

English loan words borrow large number of foreign aphorisms, slangs, and phrases making English expressive and rich. For example, no duo no die, good good study, day day up (in Chinese), jamais vu, daja vu, cherchez la femme, flea market (in French), Musse sein? Es muss seine, in feier luft (in German), in fretta, I pazzi per lettera sono I maggiori pazzi (in Italian) cover different types of concepts and word formation making English a mixture of colorful world languages.

\section{Creativity}

The openness of English language accelerated the spread of loan words and usage, benefited its assimilation of foreign words and creation of new words. English loan words substitute the original loan words with local roots or affixes making them new loan words. Other English loan words change spelling or pronunciation to make them localized. For example taikonaut, kylin, lunik, lassi, force de ftapper, westpolitik, kosher, juku, jihad, etc. This shows that in absorbing foreign culture, native speakers of English did not just copy everything from loan words but adapt them to local culture, make appropriate alterations and spread them. Modern loan words not only enrich English vocabularies but also make them vigorous and productive.

\section{Conclusion}

English has gone through many periods in which large numbers of words from a particular language were borrowed. It not only borrows from other languages but also is borrowed by others. The more contacts, the more loan words the language will acquire. The borrowing and lending lead to the merging of different languages from different nations and form new English words. Presently modern English has developed a set of scientific and technological terms common to and used by all languages as is true with politics, media, and finance. Although many words from French, German, Russian, Spanish, Japanese, and Arabic have been incorporated into English language, its wide usage, openness, flexibility, tolerance, as well as creativity make it possible to be the main body of international language in the merging of vocabularies.

\section{References}

Ayto, J. (2007). A century of new words. Oxford: Oxford University Press.

Cowie, A. P. (1975). Oxford dictionary of current idiomatic English. Oxford: Oxford University Press.

Finkenstaedt, T., \& Wolff, D. (1973). Ordered profusion: Studies in dictionaries and the English lexicon. Heidelberg: C. Winter. Speake, J. (1997). The Oxford dictionary of foreign words and phrases. Oxford: Oxford University Press.

ZHOU, L. N. (2015). American neologism and modern American culture. Beijing: China Social Sciences Press. 